\title{
CP-UDP, GEODATA, AND MAPPING NOTES ON THE USE OF MAPPING AND AVAILABILITY OF GEODATA
}

\author{
Wilbert Rodenhuis $^{1} \quad$ UDK $=912: 343.85$ \\ https://doi.org/10.18485/fb_ubur.2018.1.ch24 \\ ${ }^{1}$ Saxion University of Applied Science, Enschede, The Netherlands \\ w.k.f.rodenhuis@saxion.nl
}

\section{Summary}

The idea of making and employing maps in the context of crime prevention is obviously related to the simple fact that crimes are always spatially situated. In (environmental) criminology studies the spatial distribution of crime is analysed and related to other physical, social and economic spatially distributed characteristics of place as well as aspects of use like flows of movement (pedestrians, bicyclists, cars) and the degree of crowding. Spatially situated crime also has temporal dimensions with important variations. The aim of CP-UDP decision-making is to influence these characteristics and thus create an urban environment that is both liveable and enjoyable with less crime and perhaps just as important, with less fear of crime.

We will outline different types of geo-information that might be used as a source of knowledge on which Crime Prevention through Urban Design and Planning (CP-UDP) decision-making can be made. Based on the outcome of a survey that was sent to the COST TU 1203 members in 2016, the available data on crime and fear of crime among the member countries are presented. The quality and usability of this data might vary. We discuss in general the terms of "correctness" of maps. From there we focus on practical topics that the researcher or the CP-UDP decision-maker should be aware of before analysing the data with the appropriate techniques or before drawing conclusions on the results.

Keywords: crime prevention through environmental design and planning, methodology, crime data analysis 


\title{
CP-UDP, GEOPODACI I PREGLEDNE NAPOMENE O UPOTREBI KARTIRANJA I DOSTUPNOSTI GEOPODATAKA
}

\author{
Vilbert Rodenhojs ${ }^{1}$ \\ ${ }^{1}$ Univerzitet Saksion za primenjene nauke, Enskede, Holandija \\ w.k.f.rodenhuis@saxion.nl
}

\begin{abstract}
Sažetak
Ideja sastavljanja i korišćenja karata u kontekstu sprečavanja kriminaliteta očigledno je vezana za jednostavnu činjenicu da su zlodela uvek prostorno smeštena. U proučavanjima iz (ekološke) kriminologije istražuje se prostorni raspored kriminaliteta i povezuje sa drugim fizičkim, društvenim i ekonomskim prostorno raspoređenim obeležjima mesta, kao i aspektima upotrebe, poput tokova kretanja (pešaci, biciklisti, automobili) i stepena okupljanja (ljudi). Prostorno smešten kriminalitet takođe ima vremenske dimenzije, sa značajnim varijacijama. Cilj odlučivanja u CP-UDP-u jeste da se na ova obeležja utiče i tako stvori gradsko okruženje koje je pogodno za život i uživanje, s manje kriminaliteta $\mathrm{i}$, možda jednako važno, s manje straha od zločina.

Naznačićemo različite tipove geo-informacija koje bi se mogle koristiti kao izvor znanja na kojem se može vršiti odlučivanje u pogledu Sprečavanja kriminaliteta urbanističkim projektovanjem i planiranjem. Na osnovu ishoda ankete koja je 2016. godine bila razaslana članovima COST TU 1203 prikazani su raspoloživi podaci o kriminalitetu i strahu od zločina. Kvalitet i upotrebljivost ovih podataka mogu se razlikovati. Uopšteno raspravljamo o uslovima ,ispravnosti“ karata. Potom se usredsređujemo na praktične teme kojih istraživač ili donosilac odluka o CP-UDP-u treba da bude svestan pre nego što prikladnim tehnikama analizuje te podatke ili pre nego što donosi zaključke o rezultatima.
\end{abstract}

Ključne reči: sprečavanje zločina ekološkim projektovanjem i planiranjem, metodologija, analiza podataka o kriminalitetu 